CATALAN REVIEW

Catalan Review

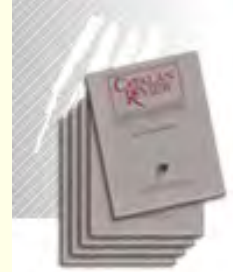

You are accessing the Digital Archive of the Catalan Review Journal.

By accessing and/or using this Digital Archive, you accept and agree to abide by the Terms and Conditions of Use available at http://www.nacs-

catalanstudies.org/catalan review.html

Catalan Review is the premier international scholarly journal devoted to all aspects of Catalan culture. By Catalan culture is understood all manifestations of intellectual and artistic life produced in the Catalan language or in the geographical areas where Catalan is spoken. Catalan Review has been in publication since 1986.
NORTH

AMERICAN

CATALAN

SOCIETY
Esteu accedint a l'Arxiu Digital del Catalan Review

A l' accedir i / o utilitzar aquest Arxiu Digital, vostè accepta i es compromet a complir els termes i condicions d'ús disponibles a http://www.nacs-

catalanstudies.org/catalan review.html

Catalan Review és la primera revista internacional dedicada a tots els aspectes de la cultura catalana. Per la cultura catalana s'entén totes les manifestacions de la vida intel lectual i artística produïda en llengua catalana o en les zones geogràfiques on es parla català. Catalan Review es publica des de 1986.

\title{
Tempting Fate: The Case against Astrology and the Catalan Response John Lucas
}

Catalan Review, Vol. XVII, number 2, (2003), p. 123-139 


\section{TEMPTING FATE: THE CASE AGAINST ASTROLOGY AND THE CATALAN RESPONSE}

JOHN LUCAS

\section{ABSTRACT}

This essay applies Valerie Flint's thesis about the adoption of astrology and derivative forms of prognostication by the medieval Catholic Church to Catalan treatises on astrology. Two main arguments against the practice of magic in the Middle Ages actually favored the development of astrology and astrological magic. By demonstrating that astrology does not subjugate free will to celestial bodies or contravene God's authority, Christian astrologers smuggled it into the mainstream of scientific practice. Catalan scholars contributed to this defense, providing textual evidence from the thirteenth to the late fifteenth centuries. The use of these two arguments to defend astrology will become so embedded in the literature that, by the late fifteenth century, such defenses appear as commonplaces. We find them even in popular texts on astrological lore, far removed from their original context as part of academic and theological discourse.

Key words: Catalonia, Crown of Aragon, Astrology, Astrological Magic, Prognostication, Ramon Llull, Thirteenth Century, Fourteenth Century, Fifteenth Century.

\section{INTRODUCTION}

Frequent and stern condemnation of astrology in the Latin Middle Ages and its subsequent vindication in the thirteenth century demonstrate a deeply-rooted fascination with the science. A slow but steady inflow of new ideas began in the twelfth century with the translation of Arabic sources and Arabic translations of Greek and Roman sources dealing with astrology. By the thirteenth century, the corpus was large enough to raise more than a few eyebrows. It would be misleading to speak of a revolution, but certainly the pressure for ideological change was building (Kieckhefer 117-19). Faced with steadfast opposition to its claims on truth, the Catholic Church eventually co-opted the worldview it found so difficult to eradicate. Finding ways to incorporate astrology and astrologically-tinged forms of prognostication into the intellectual mainstream became a major preoccupation of thirteenth and fourteenth century scholarship. As Valerie Flint observes, once astrology was partially adopted 
by the Christian church, it could be wielded as a defense against other forms of prognostication thought to be more subversive to Christian doctrine, such as sympathetic magic, geomancy, necromancy, and the like:

Astrological magic did not merely persist; it was actually given strength [...]. Astrology's extra strength came from the possibility that, in some of its manifestations, it might be used in Christian hands as a counter to these other, far more alarming, forms of divination; it might be called upon, that is, as a reinforcement to, not a contradiction of, that freedom of the will many thought to be threatened by such practices. (Rise of Magic 97).

Two basic counter-arguments to support astrology become so embedded in the literature that, by the late fifteenth century, they appear as commonplaces. This paper explores these lines of argument and reveals how Catalan scholars contributed to astrology's defense, providing textual evidence from the thirteenth to the late fifteenth centuries, when we find them in popular works on astrological lore, far removed from their original context as part of academic and theological discourse.

\section{The Case Against Astrology}

The patristic writers include astrology among the many forms of magic, categorically condemning its practice. The Church fathers, however, were not wholly consistent, and a close reading of the sources reveals some hope for future apologists of astrology. Even St. Augustine of Hippo (354-430 AD), one of astrology's most resolute opponents, left the back door open a crack for its subsequent defense. In De civitate Dei, Augustine challenges what would come to be one of astrology's most important defenses: that the stars can influence human actions only by transmitting what power they receive from God. For Augustine, a deterministic view of humankind's fate implies that the stars are responsible for its crimes as well as its achievements. Certainly we could not make such claims of God's creations. To say that the stars receive God's influence and transmit it to humankind below implies that God is responsible for human folly: "[A]re we then to think of God himself in a way which seemed completely unworthy when we were thinking of the stars as deciding?" $(5.1) \cdot{ }^{I} \mathrm{He}$ also provides

I. "[. . ]itane de ipso Deo sentiendum est, quod indignissimum visum est de stellarum voluntate sentire?" (De civitate Dei s.1) 
many proofs of astrology's inefficacy, for example in the case of twins with different life paths, but who should be subject to the same astral influences. Augustine further refutes judicial astrology, the practice of choosing auspicious days for certain events. If astrology teaches that a person's future is fixed at birth or conception, how then can a learned soul avert disaster by consulting the stars for signs of propitious moments $(5 \cdot 7) ?^{2}$

Nevertheless, in at least two respects, Augustine leaves some room for proponents of astrology to maneuver. He begrudgingly accepts that the stars might act as sign posts, indicating general tendencies in nature, although they do not affect human beings. $\mathrm{He}$ hastens to note, however, that most astrologers do not use this sort of language (De civitate Dei 5.1). Renaissance scholars will later exploit this loophole, turning magic into a sort of natural science. Augustine also accepts that the stars can have some causal influence on the physical world:

Now it could be maintained, without utter absurdity, that some influences from the stars have an effect on variations confined to the physical realm. We observe that the variation of the seasons depends on the approach and withdrawal of the sun, and the waxing and waning of the moon produces growth and diminution in certain species, such as sea-urchins and shell-fish, and also the marvelous variations of the tides. ${ }^{3}$ (De civitate Dei 5.6 )

If we accept this view, it follows that humankind is indeed subject to the influences of the stars, at least to the extent that we form a part of the physical world. St. Thomas Aquinas will take up this subject in his Summa theologiae. He accepts astrology, but only as a means to foretell effects from the causes, as a physician examines symptoms that indicate disease (2.2.95).

Augustine allows room for what we will later call white magic, although he would never have used that term himself. White magic encompasses any attempt to influence the natural world or to foretell the future by supernatural means, but always for positive ends.

2. Natal astrology predicts a person's future by studying the stars at the time of birth or conception, whereas judicial astrology examines the stars at the time the question is made or the event is to take place. If natal astrology is held to be deterministic, then it does strictu sensu run contrary to judicial astrology, as Augustine astutely observes. Judicial astrology was particularly important in the Arabic tradition, with its emphasis on lunar astrology, and hence more often subject to repression by the Church.

3. "Cum igitur non usquequaque absurde dici posset, ad solas corporum differentias afflatus quosdam valere sidereos, sicut in solaribus accessibus et decessibus videmus etiam ipsius anni tempora variari, et lunaribus incrementis atque decrementis augeri et minui quaedam genera rerum, sicut echinos, et conchas, et mirabiles aestus oceani" (De civitate Dei 5.6$)$ 
Augustine does not countenance such magic directly, but he does admit prophecy and Christian miracles, citing numerous Old Testament sources (De civitate Dei $10.8 ; 21.5)$. Augustine also staunchly defends God's foreknowledge of the future. Indirectly, this applies to adumbrations acquired through dreams and prophetic visions: "We can much better put up with those who maintain even that destiny lies in the stars than with the man who strikes out all foreknowledge of the future" (De civitate Dei 5.9.1). ${ }^{4}$

Writing over one hundred years later, St. Isidore of Seville (c. 560636AD) also struggled with astrology and magic. The enemies of the Church were somewhat different in Isidore's time than in Augustine's. The Christian Church had certainly not driven out the pagan gods and their magicians, but it was on much more solid footing, having acquired official status. The chief concern in the Middle Ages was that the astrological crafts, although potentially useful, risked invoking demons. Although medieval Christians were not to believe in Saturn, they were most certainly taught to fear Satan and his host.

In a famous passage from the Etymologiarum, Isidore of Seville (c. 560-636 AD) includes the astrologers among a long list of diviners accused of practicing magic, a demonic art and a plague on Christian society.' Nevertheless, even Isidore felt compelled to qualify his anathema. Demonstrating a more subtle understanding of astrology than is often accorded him, Isidore notes that astronomy deals with the movement of the heavenly bodies whereas astrology is partly natural (viz. scientific) and partly superstitious. It is a natural science when it observes the constellations and their position in the heavens, and it is damnable superstition when it attempts to predict the nature of men's souls and their destinies. ${ }^{6}$ In this sense, Isidore goes one step further than Augustine in accepting selected aspects of astrology.

Besides flirting with demons, astrology threatens the Church in

4. "Multo sunt autem tolerabiliores qui vel siderea fata constituunt, quam iste, qui tollit praescientiam futurorum. Nam et confiteri esse Deum et negare praescium futuorum, apertissima insania est" (De civitate Dei 5.9.1)

5. Isidore's encyclopedic Etymologiarum draws extensively on Classical texts and provides an important source for the state of learning in the Latin Middle Ages. In conclusion to a lengthy passage on magi, Isidore observes the work of demons and angels of darkness: "In quibus omnibus ars daemonum est ex quadam pestifera societate hominum et angelorum malorum exorta. Vnde cuncta vitanda sunt a Christiano, et omni penitus execratione repudianda atque damnanda." (8.9.31)

6. "1. Inter Astronomiam autem et Astrologiam aliquid differt. Nam Astronomia caeli conversionem, ortus, obitus motusque siderum continet, vel qual ex cuas ita vocentur. Astrologia vero partim naturalis, partim superstitiosa est. 2. Naturalis, dum exequitur solis et lunae cursus, vel stellarum certas temporum stationes. Superstitiosa vero est illa quam mathematici sequuntur, qui in stellis auguriantur, quiqui etiam duodecim caeli signa per singula animae vel corporis membra disponunt, siderumque cursu nativitates hominum et mores praedicare conantur." (Etymologiarum 3.27.1-2) 
two key respects. The notion that the stars foretell destiny directly contradicts the doctrine of free will. By extension, this fatalistic worldview also does violence to the sacrament of penance and reformation. More important, if destiny is immutable, Divine providence and human hope are lost (Flint, "Transmission" 2). Viewed in this light, an astrologer is a threat to established order. The Catholic Church had much reason to fear, for these non-Christian diviners offered a contrary means of understanding, predicting, and therefore controlling the natural world.

Nevertheless, intense and prolonged cultural contact between Visigothic Spain and the Islamic world led to a first revival of astrology in the thirteenth century. The Spanish schools in Toledo and Barcelona translated works on astronomy, astrology, geomancy, and sympathetic magic. According to Flint, this first revival of astrology merely brought to the surface practices that had been continued since pre-Christian times. What changed was the complicity of the Catholic Church. Faced with competing world views that were widely held, the Church had to begin a slow process of change or find itself eclipsed by other non-Christian social leaders (Flint, "Transmission" 12-18). The incorporation of Arabic material, with a caveat against opening the door to anything resembling magic or demons, provides ample material for the vindication of astrology.

St. Thomas Aquinas (1225-1274) showed some sensitivity to this emerging world-view, although he was not prepared to accept astrology outright. As Wedel observes: "He accepts judicial astrology as long as it can prove itself a part of natural science, and he goes just as far as he dares in freeing it from the restrictions with which it had become encumbered in earlier Church doctrine" (68). In the Summa theologiae, Aquinas says that the stars can influence the human senses. However, the will is superior to the senses, not being bound to any sense organ $(2.2 .95,5)$. Only the simple-minded and those who indulge in the appetites of the flesh were susceptible to harmful astral influences.

Aquinas, like writers before him, nevertheless marveled at the amazing accuracy of some astrological predictions; he is willing to go further than Augustine in accepting such predictions. In Confessiones, Augustine admits to his long-held belief in the science. As a young man, he asked a dear friend why astrology was so successful, and his companion attributed this to chance. A skeptical Augustine did not initially accept this view: "I asked him why it was that many of their forecasts turned out to be correct. He replied that the best answer he could give was the power apparent in lots, a power everywhere diffused in the nature of things" (4.3.5); "Moreover, I had not yet found the certain proof for which I was seeking, by which it would 
be clear beyond doubt that the true forecasts given by the astrologers when consulted were uttered by chance or by luck, not from the science of studying the stars" (4.3.6).7

Aquinas, however, states that mere observation of the stars is acceptable. He accepts as valid the claims of other philosophers that the stars can be causes of events in the physical world, such as drought and rain. As long as the astrologers do not attempt to foretell precise events or limit human free will, then Aquinas is prepared to accept astrology's accuracy: "Consequently astrologers are able to foretell the truth in the majority of cases, especially in a general way. But not in particular cases; for nothing prevents man resisting his passions by his free-will" (Summa 1.115, 4). ${ }^{8}$ This passage constitutes an enormous philosophical leap, if we compare it to the Roman Church's official condemnation of astrology.

Although he hesitates on the issue, Aquinas goes further than Augustine on the subject of Christian magic. He deals specifically with lot-casting, a broad term covering any attempt to discover hidden knowledge, often through the toss of a die or the random selection of a piece of scripture. Geomancy, a related form of divination also based on chance, generally falls outside the realm of acceptable Christian practice.9 According to Aquinas, the heavenly bodies do not influence the lots, so the result is either due to chance or a mediating spiritual force. Aquinas sees demons lurking behind the dice.

As is so often the case, however, the Bible itself provides counterexamples. In the book of Acts, we find the apostles casting lots to ask God for advice about whom they should elect to take Judas's place (1.26). Aquinas admits that in cases of "urgent necessity" one might seek advice in this manner, but notes that the apostles were gathered

7. "A quo ego cum quaesissem, quae causa ergo faceret, ut multa inde vera pronuntiarentur, respondit ille ut potuit, vim sortis hoc facere, in rerum natura usquequaque diffusam." (Confessiones $4: 3.5$ ); "...et nullum certum quale quaerebam documentum adhuc inveneram, quo mihi sine ambiguitate appareret, quae ab eis consultis vera dicerentur, forte vel sorte, non arte inspectorum siderum dici." (Confessiones 4.3 .6 )

8. "[...] et ideo astrologi ut in pluribus vera possunt praedicere, et maxime in communi. non autem in speciali, quia nihil prohibet aliquem hominem per liberum arbitrium passionibus resistere." (Summa theologiae 1.115,4)

9. Because geomancy also involves the interpretation of chance events, we may consider it here along with lot-casting. Geomancy involves the random casting of points in the sand or the swirling of molten metal into cold water. St. Thomas discusses different forms of divination in the Summa theologiae, although he does not mention geomancy directly. St. Isidore does count it among the proscribed forms of magic in Etimologiae 8.9. Ramon Llull also offers a critical view in the Arbre de sciencia. Geomancers, with their bizarre rituals, sought to answer specific questions. They were the medieval equivalent of television fortune-tellers, often greater believers in profit than in their craft. 
in council and consulted the lots only after fervent prayer (Summa 2.2.95, 8). Thus we have a delicate balance of ends and means. When astrology involves mere observance of causes and effects, it is acceptable. The practice might even be spiritually uplifting, providing some means of hope that we might better understand the natural world and God's path for humankind. Christian miracles, prophecies, and visions were to be accepted for their mystery. The faithful should accept God's grace in these cases and not tempt Him too much. In some extreme cases, however, one might risk a bit of vanitas and seek to know the mind of God through some permissible form of magic.

In stark contrast, scholars of the Italian Renaissance came close to conflating magic and natural science so that any attempt to influence the natural world constituted a use of "magic." That members of the Catholic Church should articulate this position indicates how much ground the occult sciences would gain (Garin 199-201). By the sixteenth century, this process of vindication was so complete that Dominican priest Tommaso Campanella (1568-1639) could argue that any act of scientific investigation constituted a use of magic; he includes the invention of gunpowder and the printing press among the many examples of magic that support his thesis. ${ }^{10}$ Marsilio Ficino (14331499), founder of Italian Neoplatonism, also defends Christian uses of magic (e.g. De Vita).

In what some have come to call the second revival of astrology, such scholars as Ficino and Campanella work out a humanistic cosmology, only complete by the end of the sixteenth century. Garin finds in Tommaso Campanella the three key propositions of this new system: "I. All sciences serve magic inasmuch as any practical art seeks to transform or control nature. $[\ldots] 2$. The mystery of the mage disappears as science advances. [. . 3 3. Despite the second proposition, the deepest mysteries are still shrouded in magic" (199-216).

In Neoplatonic cosmology, everything in the natural world is sentient. The anima mundi, or world soul, surrounds and infuses all of nature which, in turn, is composed of lesser forces. The planets themselves are living beings, lesser life forces. It is only natural that superior celestial forces influence inferior earthly ones. The human soul is a platonic middle term, mediating earthly and celestial forces, for only humankind has direct access to God through prayer and supplication and to lesser spirits through natural magic and prognostication.

10. The source is the Italian version of Campanella's De magia: "Tutto quello che si fa dalli scienziati imitando la natura o aiutandola con l'arte ignota, no solo alle plebe bassa, ma alla communità degli uomini, si dice opera magica. [. . . L'invenzione della polvere dell'archibugio e delle stampe fu cosa magica, e cosi l'uso della calamita" $(24 r-42)$. 


\section{The Catalan Response}

An examination of the textual tradition from the thirteenth to the late fifteenth centuries shows that Catalan-Aragonese scholarship participated in both of these "renaissances" of astrology. The most important writers hastened to astrology's defense by arguing that, far from thwarting free will, the science provided a means for making more informed choices. Neither did astrology challenge God's supreme reign in the heavens. Two standard arguments emerged, the first of which we may call inclinatus non determinatus. By this account, the stars only indicate tendencies that, if left unchecked, could potentially lead to disastrous consequences. The oft-repeated (pseudo-) Ptolemaic aphorism that "the wise man will rule the stars" sums up this argument.

The second defense, Thomistic in origin, and which we might call Deus causa prima, is expressed differently depending upon the culture and the time period. Essentially the argument holds that the heavens have a soul or spirit; superior to terrestrial beings, they can transmit their influence to humankind below. God, however, is the prime mover, and the stars can only pass along whatever influence they receive from God. Human free will provides the key escape clause, a way to avoid the harmful rays of the stars. Ramon Llull's particular formulation of this defense in the thirteenth century in some respects prefigures the Neoplatonic worldview we find fully developed and full of nuance in Marsilio Ficino, who argues for the practice of judicial astrology in his early works, only to write a disputatio condemning its practice later. As Bullard notes: "Ficino was not negotiating the influence of the planets so much as defending free will and providence against the determinism of those professional astrologers who claimed that the planets caused human actions and that their positions in the heavens reveal predictions of specific, future occurrences" (688). We will make similar claims of Ramon Llull, who anticipates Ficino by two centuries.

\section{ThIRTEENTH Century: Ramón Llull}

Ramon Llull (1232-1316) argues for both of these defenses of astrology more clearly than any other scholar in the Crown of Aragon. Though his early statements on astrology seem hesitant, Llull never denies the practice of astrology per se. Rather, he corrects the erroneous assumptions of the ancients who, in his opinion, fail to recognize the mitigating influence of divine authority and to understand human free will. Llull specifically licenses the practice of astrology in both of his 
encyclopedias, the Arbre de sciència (1288) and Fèlix de meravelles (1296). In the Arbre de sciència, Llull suggests to the Pope that past errors be corrected using solid scientific frameworks, such as his own Art general (r: II4-15), although he never denies astrology's usefulness: "E per açò fan mal los estronomians com tant se confizen en lo judici de les impremsions dels corses desús fetes sajús, qui en axí poden ésser destroides sobre cors d aquelles impremsions per Deu o per la voluntat franca del home, segons l'Arbre moral, axí com l'ome pot destrovir les letres impremtes en la cera per lo graffí o per lo segel" (2: 1I8-19).

To flesh out his arguments, in 1297 Llull writes the Tractatus novus de astronomia in Paris. Although the arguments are not new, the way Llull weaves his thinking on the matter into the framework of his Art general provides original nuances to the standard defenses of astrology. In this text Llull corrects technical errors of ancient astrology based upon his own reading of Arabic sources; and in the fourth section of this work, he argues against those passages of the classics that impinge upon God and the human soul. ${ }^{\text {II }}$

The first of his complaints is that Greek and Arabic astrologers treated the science as absolute, based upon a priori assumptions (Tractat 30r). Because they lack a clear scientific framework upon which to base their claims, their predictions are as often false as true (Tractat 302). Llull suggests that the ancient astronomers (viz. astrologists) erred in their understanding of the elements. Llull's theory, found in the Arbre de sciencia and expanded upon in the Tractatus novus, follows the ancients in postulating two characteristics for each element, but he suggests that one of these is essential and the other accidental. For example, fire has heat as its essential property and dryness as an accidental property, given to it by the earth. Whatever influence the planets may exert on the elements is accidental, added on, and therefore not absolute (Tractat 302). This allows Llull to postulate a more flexible form of medical astrology and opens the door to the influence of human will and divine providence, the next subject of Llull's treatise.

Llull rehearses the Thomistic formula that "Déus às prima cause dels signes e de les planetas simplament et obsoluta [... . " (Tractat 303). He argues that God, like a carpenter, may choose to drive the nail at an angle, against the natural inclination of the hammer to pound the nail straight into the wood. In turn, the "ànima del cel" or soul of the heavens may transmit divine influence to the earth below.

II. Llull's ability to deal with these Arabic sources is questionable. See Vernet, "Conocimientos astrónomicos" for a discussion. 
Although Llull argues that God can work through the stars, using them to transmit divine influence, he denies other forms of prognostication.

Llull argues against geomancy by way of exempla. He observes that a man may set out on a journey to buy wheat, spending many days before reaching the market. Naturally, this man passes under the influence of many constellations before reaching his destination. Suppose that, at the end of his travels, this man inquires of a geomancer what he is planning to purchase and the sage, after casting points, suggests "iron or silver." If geomancy were an absolute science, the man would have to change his purpose and buy something other than wheat, which is clearly not the case (Tractat 305). He suggests the real purpose behind these false prophets is lucre: "[... ] per so que los púscan enguanar e d'éls dines aver" (Tractat 305).

\section{FourteEnTH CENTURY: COURT ASTROLOGERS OF PERE III AND JOAN I}

The courts of Pere III (1335-1387) and Joan I (1387-1396) represent a period of prosperity in Catalan commerce, arts, and letters. At this time, Catalan astronomy ranked among the best in the Iberian Peninsula. The first autochthonous works date from the fourteenth century, although Catalan science still relied heavily on Arabic translations (Vernet, "Ciències exactes" 203). Catalan-Aragonese mathematics and astronomy eclipsed Castilian science, but judicial astrology was no less popular. Both of these kings jealously guarded their libraries of astrological works, commissioning many treatises in the vernacular.

Pere III brought to his court the most renowned physicians and astrologers of the time. Bartomeu de Tresbéns, who worked as his court physician from $\mathrm{I}_{36 \mathrm{I}-74}$, wrote a lengthy treatise synthesizing Greek and Arabic astrology. The work of Tresbéns predates the Renaissance, but his acceptance of astrology, when it does not impede free will, makes him a precursor to later works. With royal support for his experiments, Tresbéns did not feel compelled to include more than a mere paraphrase of the standard defenses of astrology in his treatise. In one sweeping sentence, he assures his readers that astrology does not impinge on divine authority or their own freedom: "E sàpies que totes les coses que hauem e són dites venen per la ordinació de Déu, donada a la natura per influències de les esteles en los nats, los bens e los mals, e tot és veritat pura quant és a la inclinació de la carn e de les voluntats" (Fol. 85).

He concludes with the phrase, "[E] bon esforç mal astre venç," a gloss on the Ptolemaic adage about the wise man ruling the stars. The Tractat of Tresbéns is redolent of Arabic influence, with its treatment 
of the "lots", points in the horoscope that could only be determined through complex mathematical calculation. His treatise provides an ideal example of just how thoroughly Arabic astrological sources had become interwoven into the cultural fiber of the Latin West by the fourteenth century.

In two documents from the Royal chancery, Pere III alludes to another Tractat d'astrologia and astrological tables he ordered with great haste from Pere Gilbert, Dalmau Çes Planes, and their assistant, Jacobo Corsuno, referred to simply as "jueu d'Espanya." Gilbert and Ces Planes are far more eloquent, but equally summary in their defense of the fates. They open their treatise by stating that astrology is the most noble of the natural sciences: "Entre les sciències purament naturals aquella que és de maior noblea e de maior eccellencia és la sciència de les steles" (Fol. I). Adding slightly to the argument, the authors propose that kings, philosophers, and scientists naturally study the heavens for signs of impending disaster, for the stars themselves have inspired them: "car les influències celestials en tal saber han inclinats aquells naturalment" (Fol. I). They further observe that astrology can help humankind to avert a laundry list of catastrophes: "E per aquesta sciència [. . ] pot saber l'om lo seus sdeveniments temporals $[\ldots][\mathrm{e}]$ pot aconseguir fortunes e fugir a infortunis celestials per les quals coses entre les sciències naturals aquesta és al hom de maior utilitat car lo seu enginy ne pren molt gran augment e lo enteniment maravellós e lo seyn acabat reposament" (Fol. I).

\section{Fifteenth Century: The Popularization of Astrology}

By the late fifteenth century, astrology had been completely (re)absorbed into popular culture in Catalonia, as elsewhere in Western Europe, evidenced by the many astrological almanacs, lunar charts, and similar literature published at the time. These texts, such as Granollach's Lunari (Chabàs and Roca) or Li's Reportorio de los tiempos, contain a smattering of scientific astrology, infused with popular lore and local superstition. The medieval equivalent of the Farmer's Almanac, these texts were designed to provide some basic technical data for farmers and physicians. They neither raise the specter of demons nor threaten divine providence or human free will. They do often predict general character traits for those born under a particular sign, but nothing specific enough to raise the Grand Inquisitor's eyebrow. Quite the contrary, the texts are designed to help people understand and control the natural world. Rarely do we find the slightest mention of the standard defenses of astrology in such works, for it no longer seemed necessary.

Texts on geomancy, magic, lot-casting, numerology, and future- 
telling still circulated in the fifteenth century, and these texts did incite Church condemnation. The best example in Catalan, and the only astro-numerological treatise known to exist in this language, is the anonymous Tractat de prenostication de la vida natural dels hòmens. ${ }^{12}$ A late fifteenth-century incunable, the Tractat deals with astronumerology, the prediction of the birth sign based upon the letters in one's name. Unique to this text is a direct reference to the type of astrological magic that had been condemned from the time of St. Augustine to the Renaissance. In this regard, the text prefigures the defense of magic we find in Campanella (see note ro).

By assigning numerical values to names and using them for the purpose of predicting one's future, the text raises the specter of numerology. All cultures have been fascinated by numbers, and numerical symbolism is an important feature of the Hebrew, Arabic, and Greco-Roman traditions that come together in Western Europe during the Middle Ages. The use of secret properties of numbers, however, was considered dangerous by the Church. The Tractat refers especially to the number twenty-eight, a reference to the lunar mansions of Arabic astrology.13 Partly because of its astrological associations, the Church held this number in contempt (Wedel 54, note 2). However, the Church was suspicious of all numbers, letters, and other magical symbols because they could be intercepted and interpreted by demons.

In a defense of astrology contained in the last two leaves, this curious treatise answers both of the Church's criticisms in much the same way as Ramon Llull addressed them in the thirteenth century. First, it provides an "escape clause" to allow room for the exercise of free will and secondly it asserts divine control over the stars. The clearest statement is yet another gloss on Ptolemy: "[L]o home savi senyoragarà els astres" (Fol. 12). One way a wise man might mediate the stars is through white magic, contained in "pedras preciosas e erbas; e encara animals; e segells ho pedras ab figuras; arbres e plantes, e moltas altres cosas..." (Fol. II v.) Channelled through amulets, precious gems, and plants, talismanic magic was thought to be an effective means of controlling the natural world. ${ }^{24}$ In this way, magic

12. For a detailed discussion of the contents, internal or thematic divisions, and source material of this text, see Lucas.

13. The lunar mansions (< Arabic manzil al-kamar 'mansions of the moon') refer to the revolution of the moon from one star back to the same position in approximately twenty-eight days. See Yampolsky for a discussion.

44. The use of talismans was a subject of debate filling many a Renaissance volume (e.g. book three of Ficino's De vita and Torrella's De imaginibus astrologicis [see Rotzoll]). The question centered around whether or not the use of symbols, which need an intelligent being to interpret them, necessarily implied an appeal to demons. 
functions as precursor to natural science as it seeks to manipulate the forces of nature without appeal to superior beings or demons.

Renaissance scholars provide a scientific defense for talismanic magic, one of the most superstitious forms of divination. Regarding the creation of magical symbols, Ficino observes: "[T] figures has no efficacy except in cases where it is similar in material and effect to some star from which the maker wants to receive this effect; and, in addition, where the material itself is already from the beginning of almost such a quality as you desire to render it through the figure."Is The magician's tools, because they are composed of substances similar to those found in the constellations, and not the magical symbols affixed to them, bring about the desired effect. Magic of this sort is dubbed "sympathetic" because of the affinity between earthly and celestial elements, and it becomes a sort of chemistry. As there are no symbols involved, sympathetic magic needs no recourse to spiritual beings to function. Nevertheless the practice did not earn complete acceptance in ecclesiastical circles.

It is likely for this reason that the Tractat emphasizes God's power over the stars through citations from Psalms 74 and 135 , which state that God created the sun and moon to rule day and night, offering them as signposts or warnings. It also uses St. Gregory's homily on Matthew 2 to explain the role of the stars. This chapter of the Bible created problems for the Church in the Middle Ages because it explains how an especially bright star appeared in the heavens to announce the birth of Christ and guide the magi to Bethlehem. The original Gregorian homily is a frontal attack against all forms of prognostication.

St. Gregory affirms that God chose a star to announce Christ's birth because the gentiles would not have been capable of understanding a message delivered by an angel (Fol. so). St. Gregory further notes that, in Matthew 2, the star arose in the heavens slowly until it reached Bethlehem, where it stopped over Christ's birthplace. He offers this as proof that the star was controlled by Christ and followed Him. In no way did Christ follow a destiny previously marked for Him in the stars: "But if we meditate upon the words of the gospel, in which of this very star it is said: until, arriving above the child's location, it stopped. Thus, it was not the child who hastened to

Talismanic magic, which makes use of objects inscribed with magical symbols, was highly subject to Church scrutiny.

i5. "Eadem quoque de hyacintho, topazio, smaragdo ceterisque ratio est habenda, ut fabrica figurarum non alibi efficaciam habeat, quam ubi materia cum stella congruit et effectu, a qua hunc faber exoptat accipere; ac praeterea ubi haec ipsa materia quasi iam talis est ab initio, qualem affectas reddere per figuram" (De vita 3.17.104-09). 
the star, but the star that hastened to the child. To be sure, the star was not the child's destiny, rather the newborn child was the destiny of the star" (Gregory the Great [translation mine]). ${ }^{16}$ The text glosses this passage: "Lo home no va al astre mes lo astre va al infant nat" (Fol, I2). In a delicious bit of subversive logic, the Tractat wields St. Gregory as proof that prognostication is not in disaccord with Christian theology. That the star should follow God's command by shining over Christ's birth place is proof of the benevolent nature of the stars. They serve God by providing humanity with signs: " $\mathrm{E}$ axi las stelas, planetas, et signes tots són fets a lahor de Déu omnipotent per amor del home"17 (Fol. 12). Only indirectly can the stars influence human beings, inasmuch as they transmit God's divine influence.

The Tractat deals with the star of the magi in a slightly different way from others. Marsilio Ficino, for example, argues that the star was really not a star at all but rather a comet used by God as a mere sign: "non causa Christi, sed signum" (quoted by Buhler, 359). The Tractat rather follows Llull in predicating an astrology that does indeed influence humankind but only through the influence of God as Prime Mover or First Cause. By subverting patristic sources that condemn superstition, the anonymous Tractat uses them to provide theological justification for its practice. The Tractat de prenostication is a powerful textual witness to non-Christian forms of future-telling and revisionist attempts to reframe them at the dawn of the Renaissance.

\section{CONCLUSIONS}

Astrology is part of the cultural baggage that Western Europe inherited from its Greek and Roman ancestors. Never entirely abandoned, although perhaps thoroughly rediscovered in Arabic translations in the thirteenth century, the science permeated every corner of medieval thought. Even the Catholic Church found ways to make peace with the astrologers, although only to a certain extent. As long as astrologers practised their craft within the bounds of Church

16. "Sed si euangelii verba pensamus: quibus de eadem stella dicitur: usque dum veniens staret supra ubi erat puer. Dum non puer ad stellam: sed stella ad puerum cucurrit. Si dici liceat, non stella fatum pueri: sed fatus stelle is qui apparuit puer fuit." (Pastoralis sancti Grecorii pape fol. 50 r.-50 v. Transcription mine).

17. Cecco d'Ascoli was burned at the stake in 1327 for predicting Christ's birth by means of the stars. In part, the heresy lay in the claim that Christ's life was subject to the star, or a constellation containing the star, that announced His birth in Matthew 2 (Thorndike 4:322). 
doctrine-that is, as long as they did not seek to know the mind of God, undermine divine providence, or weaken human free will-it was tolerable. Ramon Llull articulated a defence of astrology along these lines, and his words are echoed in the court astrologers and physicians who followed him. By the late fifteenth century, writers of almanacs and other popular works no longer needed to defend themselves against Church critique, beyond the mere repetition of rhetorical formulae in support of free will. The anonymous author of the fifteenth-century Tractat de prenostication, however, in his flirtation with numerology and astrological determinism felt compelled to recite in full a defence of the fates similar to the one laid down for him by many generations of scholars.

JOHN LUCAS COUNCIL ON INTERNATIONAL EDUCATIONAL EXCHANGE

\section{WORKS CITED}

AQUinas, Thomas. Opera omnia. Edited by Roberto Buso. vol. 2. Summa contra gentiles and Summa theologiae. Stuttgart: Friedrich Frommann Verlag, 1980.

Summa theologiae. Trans. Fathers of the English Dominican Province. London: Burns, Oates, and Washbourne, 1912-36. New York: Benziger Brothers, 1947-48.

Augustine of HIPPO. The City of God. Trans. and ed. Henry Bettenson. Translation of De civitate Dei. London: Pelican 1972; London: Penguin, 1984 .

- Confessions. Trans. Edward B. Pusey. Translation of Confessiones. Harvard Classics 7. P.F. Collier and Son. 1937. New York: 1965.

BUHLER, Stephen. "Marsilio Ficino's De stella magorum and Renaissance Views of the Magi." Renaissance Quarterly 43.2 (1990): 348-71.

Bullard, Melissa. "The Inward Zodiac: A Development in Ficino's Thought on Astrology." Renaissance Quarterly 43.4 (1990): 692-708.

CAMPANELLA, Tommasso. Del senso delle cose e della magia: testo inedito italiano con le varianti dei codici e delle due edizioni latine. Ed. B. Croce et al. Bari: Giusseppi Latezi i Figli, 1925.

CHABÀS, José and Antoni Roca. El llunari de Bernat de Granollachs: alguns aspectes de la bistòria de l'astronomia a la Catalunya dels quatre-cents. Barcelona: Fundació Salvador Vives i Casajuana, 1984. FICINO, Marsilio. Three Books on Life. Trans, of De vita libri tres. Trans. and ed. Carol Kaske and John Clark. Binghamton, NY: 
Binghamton Medieval and Renaissance Texts and Studies and The Renaissance Society of America, 1989.

FuINT, Valerie Irene Jane. The Rise of Magic in Early Medieval Europe. Oxford: Clarendon, I99I.

"Transmission of Astrology in the Early Middle Ages." Viator: Medieval and Renaissance Studies 21 (1990): I-27.

GARIN, Eugene. La revolución cultural del renacimiento. 2 ed. Trans.

Domenèc Bergadà. Barcelona: Crítica, 1984 .

GILBERT, Pere and Dalmau Çes Planas. Tractat d'Astrologia.

Barcelona: L'Avenç, 1890.

Gregory THE GREAT. Pastoralis sancti Grecorii pape. Venice. March

I4, I493. Biblioteca de Catalunya. [Shelf Reference: Inc. $\mathrm{I}^{-} 8^{\circ}$ ].

ISIDORE OF SEville, Etimologias. Edición bilingüe. Trans. and ed.

José Oroz Reta and Manuel Marcos Casquero. 2 vols. Madrid:

Biblioteca de Autores Cristianos, 1937.

KIECKHEFer, Richard. Magic in the Middle Ages. Cambridge: Cambridge UP, 1989 .

LI, Andrés de. Reportorio de los tiempos. Ed. Laura Delbrugge. London: Tamesis, 1999.

Lluli, Ramon. Tractat d'astrologia (segons el MS Add. 16.434 del British Museum). Eds. Jordi Gayà and Lola Badia. In Textos y estudios sobre astronomía española en el Siglo XIII. Ed. Joan Vernet. Barcelona: Universitat Autònoma, 1981.

Félix de meravellas. Ed. G. Roselló. Palma de Mallorca: 1904. Arbre de sciència. Ed. Salvador Galmés. 2 vols. Palma de Mallorca: r923.

LuCAS, John Scott. Astrology and Numerology in Medieval and Early Modern Catalonia: The Tractat de prenostication de la vida natural dels hòmens. Leiden: Brill, 2003.

Rotzoll, Maike. "Osservazioni sul De Imaginibus Astrologicis di Geronomo Torrella." Rinascimento: rivista dell'Instituto Nazionale di Studi sul Rinascimento 31 (1991): 219-37.

'THORNDIKE, Lynn. A History of Magic and Experimental Science. 8 vols. New York: Columbia UP, 1923-58.

Tractat de prenostication de la vida natural dels bòmens. c. 1485 . Barcelona: Pere Posa or Toulouse: Henri Mayer. Biblioteca de Catalunya. [Shelf number Esp. 6-8 ${ }^{\circ}$.

Tresbéns, Bartomeu de. Tractat d'Astrologia. Ed. Joan Vernet and D. Romano. 2 vols. Barcelona: Biblioteca Catalana d'Obres Antigues, 1957.

VERNET, Joan. "Les ciències exactes a la Catalunya medieval." L'Época medieval a Catalunya: Cicle de conferencies fet a la Institució Cultural del CIC de Terrassa. Curs 1980-1. Barcelona: Abadia de Montserrat, 1989. 
—. "Los conocimientos astronómicos de Ramón Llull." Boletin de la Real Academia deBuenas Letras de Barcelona 24 (1951): 187-99 WedEL, Theodore Otto. The Medieval Attitude Towards Astrology, Particularly in England. New Haven: Yale UP, 1920.

YAMPOLSKY, Philip. "Origin of the Twenty-Eight Lunar Mansions." Osiris 9 (1950): 62-83. 